\title{
Investigating barriers to demand-driven SME collaboration in low-volume high-variability manufacturing
}

DOI:

10.1108/SCM-10-2021-0486

\section{Document Version}

Accepted author manuscript

Link to publication record in Manchester Research Explorer

\section{Citation for published version (APA):}

Kazantsev, N., Pishchulov, G., Mehandjiev, N., Sampaio, P., \& Zolkiewski, J. (2022). Investigating barriers to demand-driven SME collaboration in low-volume high-variability manufacturing. Supply Chain Management: An International Journal, 27(2), 265-282. https://doi.org/10.1108/SCM-10-2021-0486

\section{Published in:}

Supply Chain Management: An International Journal

\section{Citing this paper}

Please note that where the full-text provided on Manchester Research Explorer is the Author Accepted Manuscript or Proof version this may differ from the final Published version. If citing, it is advised that you check and use the publisher's definitive version.

\section{General rights}

Copyright and moral rights for the publications made accessible in the Research Explorer are retained by the authors and/or other copyright owners and it is a condition of accessing publications that users recognise and abide by the legal requirements associated with these rights.

\section{Takedown policy}

If you believe that this document breaches copyright please refer to the University of Manchester's Takedown Procedures [http://man.ac.uk/04Y6Bo] or contact uml.scholarlycommunications@manchester.ac.uk providing relevant details, so we can investigate your claim.

\section{OPEN ACCESS}




\title{
Investigating Barriers to Demand-driven SME Collaboration in Low-volume High-variability Manufacturing
}

\author{
Nikolai Kazantsev, Grigory Pishchulov, Nikolay Mehandjiev, \\ Pedro Sampaio, Judy Zolkiewski
}

\section{Authors and contact information}

\author{
Nikolai Kazantsev ( $\square$ - corresponding author) \\ Alliance Manchester Business School, The University of Manchester, Manchester, UK \\ Graduate School of Business, HSE University, Shabolovka 26-28, Moscow, 119049, Russia \\ Exeter Business School, University of Exeter, Rennes Dr, Exeter, UK \\ n.kazantsev@exeter.ac.uk
}

\section{Grigory Pishchulov}

Alliance Manchester Business School, The University of Manchester, Manchester, UK St. Petersburg State University, $7 / 9$ Universitetskaya nab., St. Petersburg, 199034, Russia grigory.pishchulov@manchester.ac.uk

Nikolay Mehandjiev

Alliance Manchester Business School, The University of Manchester, Manchester, UK n.mehandjiev@manchester.ac.uk

\section{Pedro Sampaio}

Alliance Manchester Business School, The University of Manchester, Manchester, UK P.Sampaio@manchester.ac.uk

\section{Judy Zolkiewski}

Alliance Manchester Business School, The University of Manchester, Manchester, UK judy.zolkiewski@manchester.ac.uk 


\title{
Investigating Barriers to Demand-driven SME Collaboration in Low-volume High-variability Manufacturing
}

\begin{abstract}
Design/Methodology/approach

An exploratory study of seventeen suppliers within the European Union's aerospace industry was undertaken. The study comprised two stages. In the first stage, suppliers' answers to self-administered interviews were analysed using thematic analysis. In the second stage, interactions between the barriers were determined through interviews with experienced SME collaboration facilitators. We apply system dynamics modelling to analyse the links between barriers and identify re-enforcing and balancing loops of other factors.
\end{abstract}

\section{Purpose}

This paper adopts a multi-tier perspective and aims to explore challenges of small and medium-sized enterprises (SMEs) in collaborative manufacturing amid the emergence of dedicated B2B platforms. Original Equipment Manufacturers welcome formation of demand-driven collaborations between SME suppliers to facilitate ramp-up of production capacity. While being potentially beneficial to suppliers, such collaborations face various barriers.

\section{Findings}

We establish five major groups of barriers to collaboration impeding: (a) market transparency, (b) access to orders, (c) partner trust, (d) contracting, and (e) data sharing and coordination. We model application of four enablers that facilitate barrier removal for technology-enabled supply chains: digital platforms, supplier development, smart contracts, and Industry 4.0.

\section{Research limitations/implications}

The study is limited by the data collection from the aerospace industry; validation of the models in other lowvolume high-variability manufacturing sectors is needed.

\section{Practical implications}

The reader will learn about the barriers which impede demand-driven SME collaboration within manufacturing supply chains, interrelationships between these barriers and suggestions about how to remove them. SME cluster managers will find managerial implications particularly interesting as they will help them to overcome collaboration concerns and better prepare cluster members for Industry 4.0.

\section{Social Implications}

The models developed within this study can be used to explore the effects of intervening at critical points in the model to create virtuous improvement cycles between key barriers and related variables in the model. This can help decision making and policymaking in the area of supply chain integration. 


\section{Originality/value}

There is currently a lack of studies about how the existing barriers amplify and de-amplify themselves and what the managerial approaches to tackle the barriers are. It is unclear how far companies will go in terms of information sharing, given the trust levels, power dynamics and governance structures evident in supply chains. This study contributes by explaining the reinforcing interaction between the barriers and showing ways to overcome these using enablers.

Keywords: demand-driven collaboration, supply network, virtual enterprise, Industry 4.0, system dynamics.

\section{Introduction}

Recent years have shown a rapid increase in collaborative projects across industries, triggered by black swan events, such as COVID-19. For instance, demand-driven collaboration of Airbus, McLaren, Ford and Siemens with local medical small and medium-sized enterprises (SMEs) Penlon and Smiths helped the United Kingdom to drastically ramp up the local manufacture of emergency medical devices during a period of only 12 weeks (Microsoft, 2020). From the viewpoint of large companies, ample integration of SMEs into the supply chain allows for more innovative capacity and enhances production of products with volatile demand. For SMEs, such demand-driven collaboration allows for more work to be done with partners and capacity sharing. From the viewpoint of digitalization policies, demand-driven collaboration between SMEs contributes to developing the agenda of Industry 4.0 (Ivanov et al., 2020; Kagermann et al., 2013; Machado et al., 2020; Smit et al., 2016), as a means of product customization, which is key to low-volume highvariability manufacturing. To contribute to such production, companies are envisioned to integrate horizontally, vertically and in end-to-end directions, supported by digital platforms and other digital infrastructure (Smit et al., 2016). At the same time, SMEs are known to face challenges, such as lack of trust, infrastructure, strategic plans when instigating new collaborations (Lasi et al., 2014; Moeuf et al., 2018; Veile et al., 2020). However, these challenges remain underexplored.

In this paper we study barriers to demand-driven SME collaboration in the aerospace industry — an important case of low-volume high-variability manufacturing, which is subject to extensive product customization requirements, such as buyer/supplier furnished equipment (BFE/SFE) and stringent legislation standards, which make collaboration even more challenging than in other sectors (Schirrmann \& Drat, 2018). Although, aerospace multi-tier SMEs contribute to product innovation at all supply-chain tiers (SCE, 2017), the industry can easily be disrupted by changes instigated by 
their large customers. For example, Airbus triggered a structural change by reducing direct supply relationships with more than 6,000 multi-tier suppliers in the favour of first-tier suppliers (Bernhard et al., 2007; Rossen et al., 2015; SCE, 2017) and becoming a 'system integrator' (Janke et al., 2007). This implied close cooperation with their first-tier suppliers (referred also to as Risk Sharing Partners - RSPs), whilst other suppliers are expected to collaborate with each other and RSPs to stay in business, as illustrated in Figure 1. This limits assimilation of new innovative SMEs and start-ups into the aerospace supply chain, as their direct supply to this OEM is restricted (Schirrmann \& Drat, 2018).

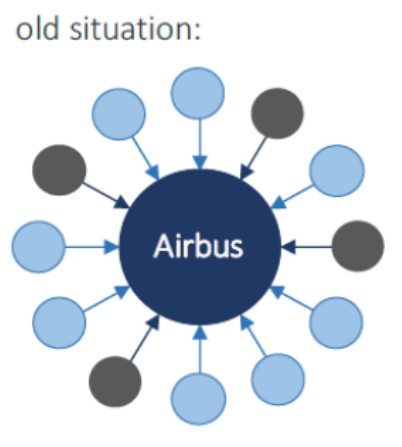

System supplier (RSP)

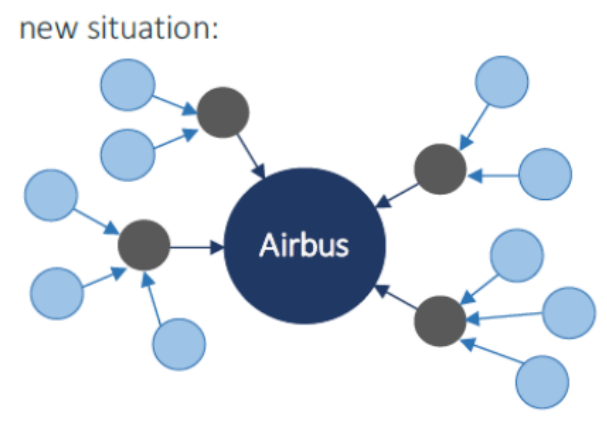

Non-system supplier (tier $\mathrm{n}$ )

Figure 1. Airbus's refocusing on RSPs triggers changes in aerospace B2B supply relationships. ${ }^{1}$

Extant research provides little insight into barriers that SMEs face when trying to initiate a new demand-driven collaboration, how these barriers affect each other, and what are the managerial approaches to overcoming these barriers (Liao et al., 2017; Moeuf et al., 2018). For instance, the established research in low-volume high-variability manufacturing, considers SMEs individually, not in the scope of other suppliers (Mittal et al., 2018; Moghaddam \& Nof, 2018; Panetto et al., 2019). We know that SMEs lack clear best practices about how to initiate collaborations on demand (Frank et al., 2019; Raj et al., 2020), face barriers to knowledge sharing (Konsti-Laakso et al., 2012; Zeng et al., 2010) and to collaboration intention (Martin et al., 2019), but there were no systematic investigations of SME collaboration during the structural change of an industry. Further, the barriers identified in the literature for long-term collaborations, such as strategic alliances, refer to strategic issues and do not consider related tactical challenges, e.g., to demand fluctuations or demand shocks, which can be addressed through collaboratively, e.g., by ramping up production in an emergency.

\footnotetext{
${ }^{1}$ https://www.digicor-project.eu/the-project/ (accessed 1 April 2021)
} 
Response to demand-side disruptions may require SMEs to spend much time in reaching an agreement before a new collaboration may start (Frank et al., 2019; Kazantsev et al., 2018; Luthra \& Mangla, 2018). Therefore, uncovering barriers to demand-driven collaborations would inform firms about the potential pitfalls on the collaboration journey and effective ways of addressing these.

Our study contributes to closing this gap by conducting an in-depth investigation of such barriers, interdependencies between them, and exploring how to facilitate formation of demand-driven SME collaboration. We state our research questions as: What are the barriers to demand-driven SME collaboration? What are the interdependencies between the barriers and possible means of barrier reduction?

To answer these questions, our study was conducted in the context of an EU-funded project aimed at building a digital platform for demand-driven SME collaborations in the aerospace industry, which is known to be reliant on collaboration between suppliers (Turkina et al., 2016). The study included two stages. In the first stage, 17 aerospace suppliers to a leading European aerospace manufacturer were interviewed about their experiences of establishing new collaborations. Our analysis identified fifteen collaboration barriers; these were explored in the second stage using system dynamics to model interdependencies between the barriers, derive insights into the causes of the variation in barrier strength, and identify enablers that could overcome them. In so doing, we identify four enablers: digital platforms, supplier development programmes, smart contracts, and Industry 4.0 technologies. Hence, we contribute to production research by explaining the reinforcing interaction between the barriers and showing how the enablers overcome the barriers. The remainder of the paper is organised as follows. Section 2 reviews related literature. Section 3 presents the methodology. Sections 4 and 5 report on findings: barriers to demand-driven collaborations and causal loop models showing their reduction. Section 6 provides a concluding discussion.

\section{Literature review}

SMEs are key to the world economy, accounting for about $90 \%$ of businesses and over $50 \%$ of jobs (World Bank, 2021). Across the OECD, SMEs comprise about $99 \%$ of all firms, about $70 \%$ of jobs, and generate up to $60 \%$ of value added (OECD, 2017, 2020). The review begins by exploring the experience of SMEs in relation to Industry 4.0, continues by overviewing demand-driven collaboration between SMEs, and finishes with the research gap in supply-side SME collaborations. 


\section{SMEs' interconnectivity in Industry 4.0}

Industry 4.0 is "an integrity of technologies, organisational concepts and management principles underlying a cost-efficient, responsive, resilient and sustainable network, data-driven and dynamically and structurally adaptable to changes in the demand and supply environment through rapid rearrangement and reallocation of its components and capabilities" (Ivanov et al., 2020, p. 2). In the context of SMEs, Industry 4.0 prescribes a new scale of interconnectivity between partner companies (Bauernhansl et al., 2014; Lasi et al., 2014; Moeuf et al., 2018; Spath et al., 2013), which contributes to digitisation of production processes along the entire value chain (Kagermann et al., 2013) but may require a substantial financial investment (Smit et al., 2016). Recent work (Ivanov et al., 2018; Olsen \& Tomlin, 2020; Tang \& Veelenturf, 2019) shows that extant research predominantly focuses on the manufacturing applications of the technologies in large plants. Although fewer studies have addressed application of Industry 4.0 principles and practices involving SMEs (Ivanov et al., 2019; Ivanov et al., 2020), some hurdles to SMEs' adoption of Industry 4.0 have been identified, see Table 1. Barriers to Industry 4.0 for SMEs identified in the literature

Table 1. Barriers to Industry 4.0 for SMEs identified in the literature.

\begin{tabular}{|c|c|c|c|}
\hline & Barrier name & Barrier description & Source \\
\hline 1 & Lack of benefit & $\begin{array}{l}\text { Lack of clarity regarding economic } \\
\text { benefit of Industry } 4.0\end{array}$ & $\begin{array}{l}\text { (Mittal et al., 2018; Raj et al., 2020; Xu } \\
\text { et al., 2018) }\end{array}$ \\
\hline 2 & $\begin{array}{l}\text { Lack of Industry } \\
4.0 \text { infrastructure }\end{array}$ & $\begin{array}{l}\text { SMEs mostly apply inexpensive and } \\
\text { less revolutionary solutions, lack of } \\
\text { reference architecture. }\end{array}$ & $\begin{array}{l}\text { (Batz et al., 2018; Konsti-Laakso et al., } \\
\text { 2012; Mahmood et al., 2021; Moeuf et } \\
\text { al., 2018; Zeng et al., 2010). }\end{array}$ \\
\hline 3 & $\begin{array}{l}\text { Lack of digital } \\
\text { culture, skills }\end{array}$ & $\begin{array}{l}\text { SMEs lack digital skills to operate } \\
\text { data-driven IT tools. }\end{array}$ & $\begin{array}{l}\text { (Frank et al., 2019; Mahmood et al., } \\
\text { 2021; Moeuf et al., 2018; Raj et al., 2020) }\end{array}$ \\
\hline 4 & Lack of strategy & $\begin{array}{l}\text { SME management structures leave } \\
\text { new technologies under-exploited. }\end{array}$ & $\begin{array}{l}\text { (Horváth \& Szabó, 2019; Klein et al., } \\
\text { 2018; Moeuf et al., 2018). }\end{array}$ \\
\hline 5 & Lack of flexibility & $\begin{array}{l}\text { SMEs are known to find it hard to } \\
\text { accept organizational change. }\end{array}$ & $\begin{array}{l}\text { (Batz et al., 2018; Mittal et al., 2018; Raj } \\
\text { et al., 2020). }\end{array}$ \\
\hline 6 & Lack of resources & $\begin{array}{l}\text { SMEs are known to lack capital to } \\
\text { apply Industry } 4.0 \text { technologies. }\end{array}$ & (Mittal et al., 2018; Müller et al., 2018) \\
\hline
\end{tabular}

\section{Demand-driven collaboration}

In the context of supply chain management, the term collaboration typically means transformation of conventional supplier-buyer relationships into partnerships within a network, facilitating joint product design and deployment of integrated logistics (Ross \& Rogers, 1996). The studies by 
Zimmer et al. (2016) and Glock et al. (2017) review approaches to collaborative supplier relationship management from the buyer's perspective. For buyers such as Original Equipment Manufacturers (OEMs), SME collaborations are considered strategically important to improve product innovation (Batz et al., 2018; Hernández \& Pedersen, 2017) and risk management (Dubey et al., 2021; Ivanov et al., 2019; Ivanov et al., 2020). In contrast, from a supplier's perspective, collaborations occur between multi-tier suppliers towards joint demand fulfilment. Demand-driven collaborations are typically initiated in response to an emerging business opportunity characterized by a limited time frame, fewer members, and contractual commitment (Schirrmann \& Drat, 2018, p. 9). By initiating and accepting demand-driven collaborations, SME suppliers can access other industries and utilise their excess capacities "for a specific business goal at a specific moment in time" (Grefen, Eshuis, et al., 2009, p. 89). Virtual Enterprises are a common inter-organizational structure for SMEs initiating such projects (Camarinha-Matos, 2009; Grefen, Mehandjiev, et al., 2009; Ivanov et al., 2010; Sokolov \& Ivanov, 2015).

\section{Barriers to demand-driven collaboration}

A barrier to entry (collaboration) is anything that "prevents entry when entry is socially beneficial" (Fisher, 1979, p. 23). The existing literature on supply chain alliances reports on structural, sociological, organizational and individual barriers, which "reinforce each other to undermine collaborative behaviour" (Fawcett et al., 2015, p. 648) and lead to supply chain collaboration failure. From an SME's perspective, large manufacturers are dominant in the market and exercise their power when selecting suppliers (Schwab, 2017), which signifies knowledge and power imbalance in supply chains (Fawcett et al., 2008).

In contrast to opportunity-independent strategic alliances, partners of time-limited demand-driven collaborations do not align strategies, and partnering SMEs keep their own business objectives. Differences in business culture (Borys \& Jemison, 1989; Camarinha-Matos et al., 2017) increase risks of partners' opportunistic behaviour (Melander \& Lakemond, 2015). SMEs often lack common forms of contractual coordination (Villa \& Bruno, 2013), which undermines trust (Reaidy et al., 2015) - a necessary precondition for collaborations (Guo-Qiang \& Ji-Ying, 2006). SMEs spend much time trying to agree on many issues before a new collaboration may start (Frank et al., 2019; Kazantsev et al., 2018; Luthra \& Mangla, 2018). They further lack technological infrastructure (Michaelides et al., 2013) and face barriers to information exchange (Klein et al., 2018). Taken 
together, there are significant barriers to demand-driven collaborations which impede SMEs' participation in such time-limited business opportunities. Therefore, enablers to demand-driven collaboration are required.

\section{Enablers to demand-driven collaboration}

Faustino et al. (2019) identified governance, geographic proximity, and trust as the main enablers of SME collaboration. Regional SME clusters provide access to knowledge (Götz \& Jankowska, 2017), connections to external markets (Villa \& Taurino, 2018) and supplier development programs, such as networking and socialization mechanisms, favouring demand-driven collaboration (Götz \& Jankowska, 2017). Managers in clusters act as innovation orchestrators by resolving communication problems between SMEs (Batz et al., 2018). A prominent example of a cluster with a supplier development programme is Virtuelle Fabrik - a regional manufacturing network in Switzerland that supports short-term cooperations (Katzy \& Crowston, 2008). By integrating SMEs' internal resources with complementary activities of their partners, clusters employ new collaborative business models (Dalmarco et al., 2019). In turn, the informal linkages that firms establish develop trust over time (Connell et al., 2014 ; Niu, 2010). This contributes to a reduction in transaction costs by creating collective actions and common goals that reduce opportunistic behaviours (Liao, 2010).

Clusters may employ digital platforms to let companies access a shared pool of resources during a demand-driven collaboration (Faustino et al., 2019). Platforms match customers, suppliers and partners, standardise contracting, and trace actors' reputation (Schor, 2014). By so doing, platforms facilitate formation of demand-driven collaborations (Thomas et al., 2014), bring innovations to products (Adner \& Kapoor, 2010; Payne \& Frow, 2016; Thomas et al., 2014), aid in increasing SMEs' collaboration efficiency (Connell et al., 2014) and problem-solving (Hoffmann et al., 2014; Niu, 2010). Such platforms are popular in Chinese manufacturing (MacCarthy et al., 2016) and are emerging in the EU (Veile et al., 2020), such as the EU-funded project EFPF².

\section{Research gap}

It appears that SMEs need to overcome significant hurdles to become successful players in future Industry 4.0 developments (Decker, 2017; Sommer, 2015). In this regard, demand-driven collaboration and its enablers are often seen as ways for SMEs to overcome some of the barriers.

\footnotetext{
${ }^{2}$ https://www.efpf.org/ (accessed 1 April 2021)
} 
Earlier simulations of manufacturing services and components delivered by a collaborative network of organisations have shown increased demand for manufacturing flexibility, customization, higher market responsiveness, shorter lead times and better capacity utilization (Moghaddam \& Nof, 2018), but assume that all SMEs are 'willing to collaborate', which rarely happens in practice. There is an incomplete understanding of why for-profit companies do not collaborate when a collaboration actually provides tangible benefits (Ferrell et al., 2020). The reasons for non-participation of SMEs in demand-driven collaborations as well as the incentive schemes to encourage participation and share gains between SMEs are underexplored (Ferrell et al., 2020).

As such, there are industries, specifically aerospace, where demand-driven supplier collaboration is expected (Schirrmann \& Drat, 2018), but suppliers are reluctant to collaborate (Turkina et al., 2016). It is not uncommon for such industries to require 'low-volume high-variability' manufacturing capabilities in order to produce extensively customized products, such as bespoke aircraft, and cope with demand uncertainty. Recent years have witnessed new research on supply chain collaboration in the aerospace industry addressing (a) decision support tools for forming Industry 4.0 supply chain collaborations (Cisneros-Cabrera et al., 2021; Cisneros-Cabrera et al., 2018; Ramzan et al., 2017); (b) application of Internet of Things to improve project planning and implementation of aerospace project-driven supply chains (Ethirajan \& Kandasamy, 2020); (c) risk and reward sharing, which improves collaboration among the partners (Braziotis et al., 2017). In most of this research, trust was cited as being crucial for developing inter-organisational relationships in the aerospace industry (Varoutsa \& Scapens, 2012). The three largest obstacles to the digital integration of suppliers in the aerospace industry were found to be: the lack of pre-configured IT interfaces, insufficient standards for supply chain processes, and paucity of standards for IT tools (Stegkemper, 2016). However, these insights represent only an aggregate view, falling short of a finer-grained analysis and practical recommendations.

Therefore, we formulate our research questions as: What are the barriers to demand-driven SME collaboration? What are the interdependencies between the barriers and possible means of barrier reduction?

To date, a number of barriers to supply chain collaboration have been identified, but these are considered (a) in long-term strategic alliances; (b) from a buyer perspective; and (c) detached from 
the Industry 4.0 context. The latter perspective is important especially given the added technological complexities brought by Industry 4.0 that, in turn, may either reinforce or diminish the barriers. Our work explores this gap by empirically investigating the perceived barriers to formation of demanddriven collaborations, initiated in response to an emerging, short-lived business opportunity. In so doing, we particularly focus on potential collaborations between SMEs in the presence of digital platforms.

\section{Methodology}

Our research approach follows the interpretivist paradigm (Saunders et al., 2007), which is the philosophical stance focusing on exploration of the complexity of social phenomena and aiming to understand the meanings that others have of the phenomena. Contextual relevance is an integral part of the interpretivist philosophical stance (Morgan, 2007). In this research, understanding of meaning is achieved through inductively developed patterns constructed through exploration of rich data (McKie, 2002). A qualitative exploration was needed because the current understanding of this particular phenomenon is incomplete (Miles \& Huberman, 1994). This particular style of enquiry allows for exploration through the collection of rich data, such as self-administered paper-and-pencil interviews (Kim et al., 2008).

\section{Research context and sample selection}

The Association of Aerospace SMEs (AAS) represents a supplier cluster in Northern Germany comprising a wide spectrum of aerospace suppliers (about 150 companies in the period of the study), which supply a major aerospace corporation (MAC) and its Tier-1 suppliers. The established aerospace value chain starts from MAC, who places orders in the form of calls for tenders (CfTs) and disseminates these documents among its largest Tier-1 suppliers. Tier-1 suppliers typically invite their established SME partners to supply sub-assemblies and services. The process is predominantly manual, lacks transparency and poses significant capacity and capability requirements for individual suppliers. Both MAC and its suppliers are interested in facilitating demand-driven collaborations within and across lower tiers, such collaborations can better meet MAC demands and increase the volume of business for AAS members. AAS is a very good context to study inter-firm barriers, as firms in the aerospace industry are known to be reliant on collaboration between suppliers (Turkina et al., 2016). Keeping in mind the reluctance of manufacturing SMEs to respond to surveys (Müller et al., 2018), we asked an AAS executive, twice, 
to invite (via e-mail) CEOs of their member companies to fill a semi-structured paper-and-pencil interview (Kim et al., 2008), in a time convenient for them. This method is also known as a selfcompleted questionnaire (Saunders et al., 2007), and uses open questions to explore the key areas of interest. We received a positive response from 17 AAS members (see Table A1; all participants have been anonymised), which we consider sufficient for qualitative exploration due to the exploratory nature of the study. Of the 17 respondent companies, 14 (82\% of the sample) employ fewer than 250 staff and have an annual turnover of up to $€ 50 \mathrm{~m}$, thus meeting the EU's classification criteria for SMEs, whereas three companies (18\% of the sample) exceed one or both thresholds. We still retain all respondent companies in the sample as this warrants a better representation of the supplier cluster and the collaboration barriers between its members, comprised predominantly of SMEs.

\section{Interview design}

We prepared interview questions (Table A2) focused on supply chain collaborations and covering: (i) company information; (ii) priorities and activities in searching for partners; (iii) barriers to vertical supply chain collaborations; (iv) perceived impact on business; (v) barriers to horizontal collaboration between suppliers; (vi) benefits of horizontal collaborations; (vii) IT-related barriers to collaborations; and (viii) how the company could overcome the barriers. Questions in groups (ii)(viii) were open-ended, allowing respondents to itemise their own responses. In agreement with the AAS executive, the term 'Industry 4.0' was not explicitly included in the wording of questions, as the conceptual vision of digital transformation might have positively biased the respondents regarding the current barriers. The questions were reviewed by all team members and translated from English into German by a bilingual AAS executive, who also provided back-translation of the responses. The questionnaires were completed by the respondent companies between October 2016 and February 2017.

\section{Thematic analysis}

We employed thematic analysis of the data, a method that seeks to find themes of interest in the dataset (Braun \& Clarke, 2006; King \& Horrocks, 2010). It allows researchers to reassess the predefined initial ideas through "inductive contact with the data" (Fereday \& Muir-Cochrane, 2006, p. 88). Such an approach is suggested for investigating "commonalities between [a] set of companies rather than analysis of individual cases in greater depth" (King \& Horrocks, 2010, p. 159). We 
followed the abductive procedure of Dubois and Gadde (2002), i.e. evolving the theoretical, empirical fieldworks, and case analysis simultaneously. Figure 2 illustrates the coding model.

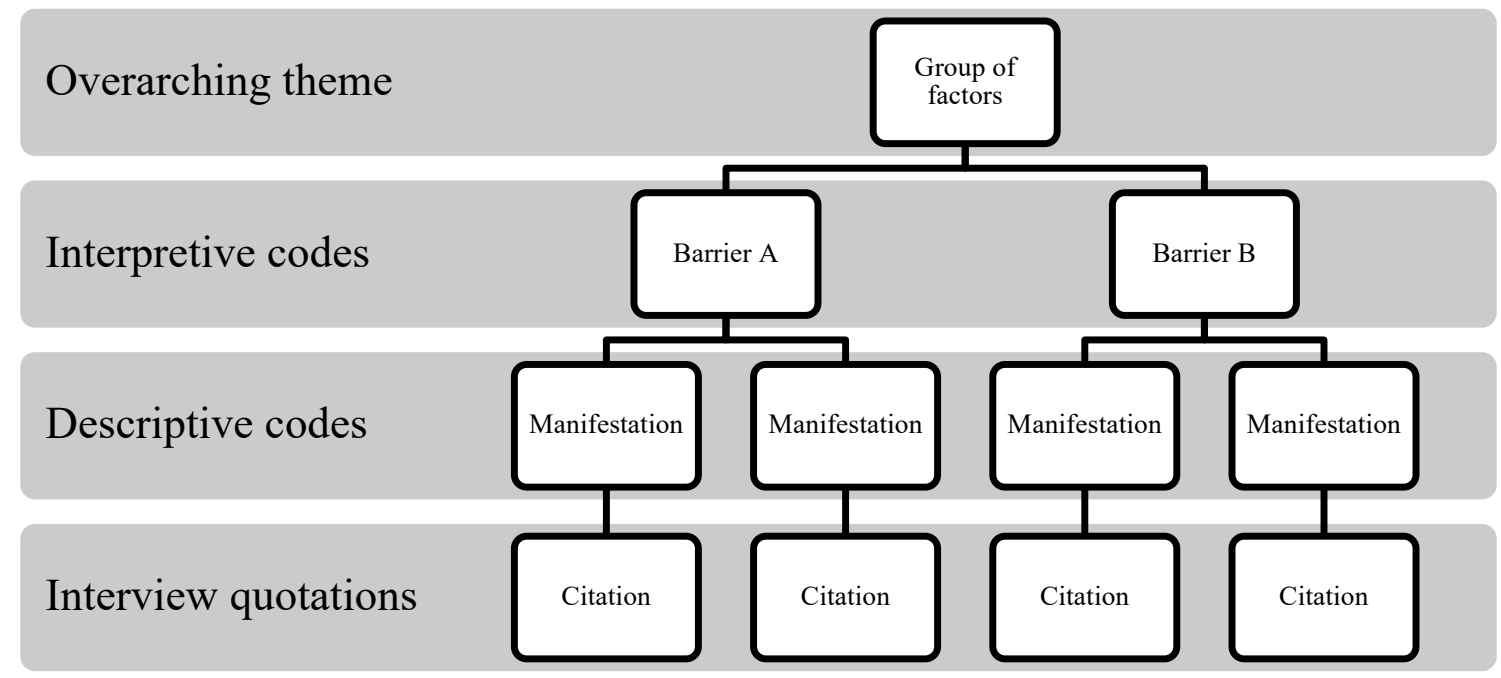

Figure 2. Representation of the coding model.

The answers were thematically coded, through an interpretive process of detailed reading and reviewing of the content (Dubois \& Gadde, 2002), and the descriptive themes were grouped into interpretive themes. In the process, we agreed the inclusion of new sub-categories as they appeared from the data (King \& Horrocks, 2010). When the analysis no longer identified any new codes, we confirmed theoretical saturation and, therefore, the final coding structure (Bryman, 2008; Silverman \& Marvasti, 2008). Inter-coder reliability was ensured by following an iterative process for analysing content using documented peer-review and reflection of our coding (Creswell \& Miller, 2010) contributing to the reliability of the study (Miles \& Huberman, 1994). Any differences were resolved through peer-review and discussion (Kassarjian, 1977). To remove the observer-bias (Eisenhardt \& Graebner, 2007), external validity was ensured through the review of previous literature on collaboration challenges. After the thematic analysis was completed, we presented the initial barriers to three of the respondent companies during the Hamburg Aircraft Interiors Expo 2018 to obtain feedback ${ }^{3}$ and enhance the validity (Crabtree \& Miller, 1999). Furthermore, we assured the respondents' full anonymity and confidentiality, addressing potential key informant bias.

\footnotetext{
${ }^{3}$ Recordings are available upon request.
} 


\section{System dynamics}

As recommended by Sterman (2000, p. 158), in the second stage of our study we undertook an indepth interview with two industrial experts from MAC and AAS, who had more than 20 years of experience in the aerospace industry, where we presented the identified barriers and discussed the interrelationships between them and suggestions for how they could be removed. We employed the system dynamics methodology to represent the interrelationships between the barriers and the potential effect of managerial intervention by means of the enablers. Prior to the interview, the experts were introduced to the system dynamics methodology. Following participative business modelling (Akkermans \& Van Wassenhove, 2018), we allowed experts to propose any interrelations between the barriers they considered appropriate. Iteratively we developed causal loop diagrams to model the state of the barriers before and after suggested managerial intervention, which we showed to the same experts one year later to confirm the validity of models.

\section{Findings}

In the first stage of this study, we report on 15 manifestations of barriers to supply-side SME collaborations and five overarching themes.

\section{Overarching theme 1: Barriers impeding market transparency}

\section{Barrier A1. Customer search costs}

This barrier describes the costs of identifying potential customers in the supply chain. These include employees' time, travel and accommodation expenses incurred in attending physical meetings. 15 out of 17 companies mentioned the need to attend international trade fairs and presentation events to find new customers.

\section{Barrier A2. Partner search costs}

Companies' responses reveal that they lack experienced partners. Costs of partner search comprise the need for physical meetings and interaction with international companies (see also barrier A1), and the accumulation of these costs poses a significant financial hurdle to SMEs. In addition, supplier 3 noted that the 'networking time is missing' and this is another obstacle to preparing a timely collaborative tender. 


\section{Barrier A3. Marketing costs}

Respondents mentioned the marketing spend required to sustain 'reputation and marketing effort' in the eyes of potential customers (supplier 13) and 'for better visibility and public relations', as perceived by supplier 12. Otherwise, it is 'very difficult to find new customers' (suppliers 9, 15).

Barrier A4. Lack of knowledge about starting new relationship in Industry 4.0

Companies regard joining networks as a way 'to exchange knowledge' (supplier 15), 'to stay close to the market and recognise trends' (supplier 13) and to gain 'access to additional market intelligence' (supplier 1). They complained about their knowledge imbalance in networks regarding initiation of new relationships. Supplier 8 mentions 'minor knowledge about industry 4.0'.

\section{Overarching theme 2: Barriers impeding access to customer orders}

\section{Barrier B1. Suppliers unable to meet the tender requirements}

Our data suggest that suppliers lack production resources to sustain the typical delivery volume stipulated in the purchase conditions of MAC orders. Supplier 1 that produces composite aircraft parts claims: 'the size of our company is too small for very high-volume contracts with OEM'. Such strategic misalignment due to size, financial strength, capacity, and qualified staff deficit does not allow SMEs to deliver to MAC. Additionally, the strict industrial certification requirements of the aircraft supply chain impose costly, complex and slow certification processes on SMEs. As a result, SMEs cannot fully satisfy certification requirements of a typical MAC order.

\section{Barrier B2. Lack of direct access to downstream orders}

The data suggests that most of the aerospace sourcing agreements of the MAC are with large companies that act as intermediaries. Large Tier-1 suppliers tend to have a long history of doing business with the MAC and they were perceived as reluctant to change arrangements with their existing partners, as supplier 16 explains: 'big customers want to have all services from one source'. Other evidence suggests that 'call for tenders of the OEM are made only for tier-1' and procurement practices "ensure" that 'no direct bidding to OEMs [is] possible', as perceived by supplier 6 . Supplier 10 indicates that 'changes and improvements in [tendering] work flow routines in big companies are very limited'.

As MAC orders are distributed among Tier-1 suppliers only, these companies protect their market power, as explained by supplier 2, by 'filter[-ing] relevant information from the OEM'. Since Tier- 
1 suppliers tend to disseminate unattractive remaining work packages to smaller suppliers, SMEs must work under their dominion rather than find partners with complementary capabilities themselves. Supplier 6 also mentions 'late call for tenders' from MAC as a reason for having 'short time for generating offers' in collaboration and 'bad comparability' of such collaborative offers by MAC (supplier 4). Additionally, respondents mention 'very short-term information about changes' in requirements (supplier 14), which are imposed for 'quick fixes instead of exploiting the available [collaboration] potential' (supplier 15).

\section{Barrier B3. Lack of understanding of requirements}

The data suggests that tender requirements are not clear enough to allow suppliers to gauge their suitability for collaborative delivery with other companies. Suppliers express concerns that customer order specifications are 'vague', 'unclear', and this could be explained by suppliers' weak bargaining power, or by the lack of industrial knowledge. Supplier 17 claims that since the 'contact person at the customer is unknown', there is no chance to ask questions.

\section{Overarching theme 3: Barriers impeding partner trust}

\section{Barrier C1. Partner opportunism}

Suppliers state that it is hard to avoid 'competition thinking' and 'to find common goals', as perceived by supplier 1. Supplier 2 explained this competitiveness by the differences in business culture between countries. Unwillingness to cooperate pushes suppliers to extract maximum benefit from collaborations whilst applying minimal efforts in exchange. This is confirmed by the testing equipment supplier 15 who insists that 'some SMEs are looking for the "cheap win": i.e. getting as much out of collaboration as possible without providing anything “in exchange”'. Supplier 14 suggests that partner 'matching' would result in a 'win-win-situation' that involved all partners 'in the same way'.

\section{Barrier C2. Partner distrust}

Distrust was evident in several responses. Supplier 15 reported that there is '(no) willingness to further develop external ideas [that are] not invented by them [and] top management [of other companies] disapprove of the idea of collaborating with other organisations altogether'. Suppliers 10 and 17 indicate that smaller suppliers are unwilling to give information to them. Supplier 10 also complains that 'evaluation of own suppliers can't be done because reluctance of those to deliver the 
required information'. Companies also do not share forecasting data. Furthermore, some suppliers mentioned intentions 'to spy for solutions of competitors' (supplier 16). Supplier 2 recollects that when they temporarily used the infrastructure of larger suppliers, the latter hired their best staff.

\section{Overarching theme 4: Barriers impeding contracting}

Barrier D1. Restrictive contracting practices

Supplier 17 indicates customers' 'unwillingness to change suppliers'. Supplier 8 further elaborates that larger suppliers have long-term agreements with MAC and smaller suppliers 'can't take part in tenders, if they don't have a contract with OEM'. Supplier 12 mentions that this is due to '[poor] contractual conditions', such as focus on long-term agreements with large volumes that are unsuitable. Supplier 13 mentions 'long-term contract terms with changing business content' that are also unsuitable. Furthermore, several suppliers have pointed to a price-only focus on market competition, which disregards other performance attributes — such as quality.

Barrier D2. Partner contracting costs

Supplier 8 recalls the differences in 'international systems for law, taxes ....' and that it takes 'long time to find right regulations' to arrange a contract (supplier 14) and to decide about the 'role[s] in the cooperation (Who is the contractor?)' (supplier 1). Furthermore, supplier 8 explains that 'SME partners want to have own contracts with the customer'. Supplier 10 mentions 'different levels of readiness to accept a [contracting] risk'. Supplier 12 confirms that 'risks can't be given to other partners in the network or can't be shared'.

Barrier D3. Knowledge protection costs

The identified knowledge protection obstacles embrace 'IP- and knowledge-management in projects [that] disable cooperation' (supplier 15). A cabin interiors supplier 8 recalls differences in 'international systems for patents', which makes it difficult to understand the way some of partners' IP could be used. Supplier 5 further indicates 'problems with [protecting] intellectual property', and supplier 6 - 'time-consuming non-disclosure agreements'. Due to a lack of formalised company-specific policies, negotiating non-disclosure agreements between partners takes a long time due to differences in legal, fiscal and patent systems. 


\section{Overarching theme 5: Barriers impeding data sharing and coordination}

Barrier E1. Costs of data interchange with customers

Although some companies are ready for information exchange, supplier 2 reveals the lack of 'direct IT-interface to the [OEM] systems', which is allowed only through larger suppliers. Supplier 16 recalls 'time-consuming calibration because of missing knowledge for operating devices of customers', and supplier 13 concludes that 'worldwide integration [of suppliers] can be difficult because of different IT-systems and/or behaviour of staff'.

Barrier E2. Lack of ability to utilise partners' data

Respondents reported obstacles that hamper data exchange between partners, such as 'unfit technological delivery specifications', as perceived by supplier 6. Supplier 8 commented on 'missing standards and interfaces in communication' and 'proprietary IT-systems without adequate standards for data transfer'. Supplier 15 added the lack of 'optimisation in information flows and communication for structured data exchange'. Additionally, supplier 10 mentions poor management of 'data exchange such as CAD and digital platforms/portals'.

\section{Barrier E3. Cost of lack of coordination}

Six respondents cited inefficient inter-organisational cooperation, including lack of accurate forecasting, and information gaps relating to customer order fulfilment, especially to customer requirements. Supplier 16 mentions information loss due to 'Chinese whispers effects in communication'. Supplier 6 adds that it implies 'long production cycles of suppliers [shift] estimated delivery time and [therefore] delivery requirements of customers [are getting] not compatible’.

\section{Summary}

For the AAS supplier cluster, five overarching themes and 15 barriers have been found, which were organized according to the number of quotations of each barrier, see Table A3 and Figure 3. We caution the reader against overinterpreting the most frequently cited barriers as most substantial ones; they shall be understood as the barriers that have occurred most frequently across the study sample. 


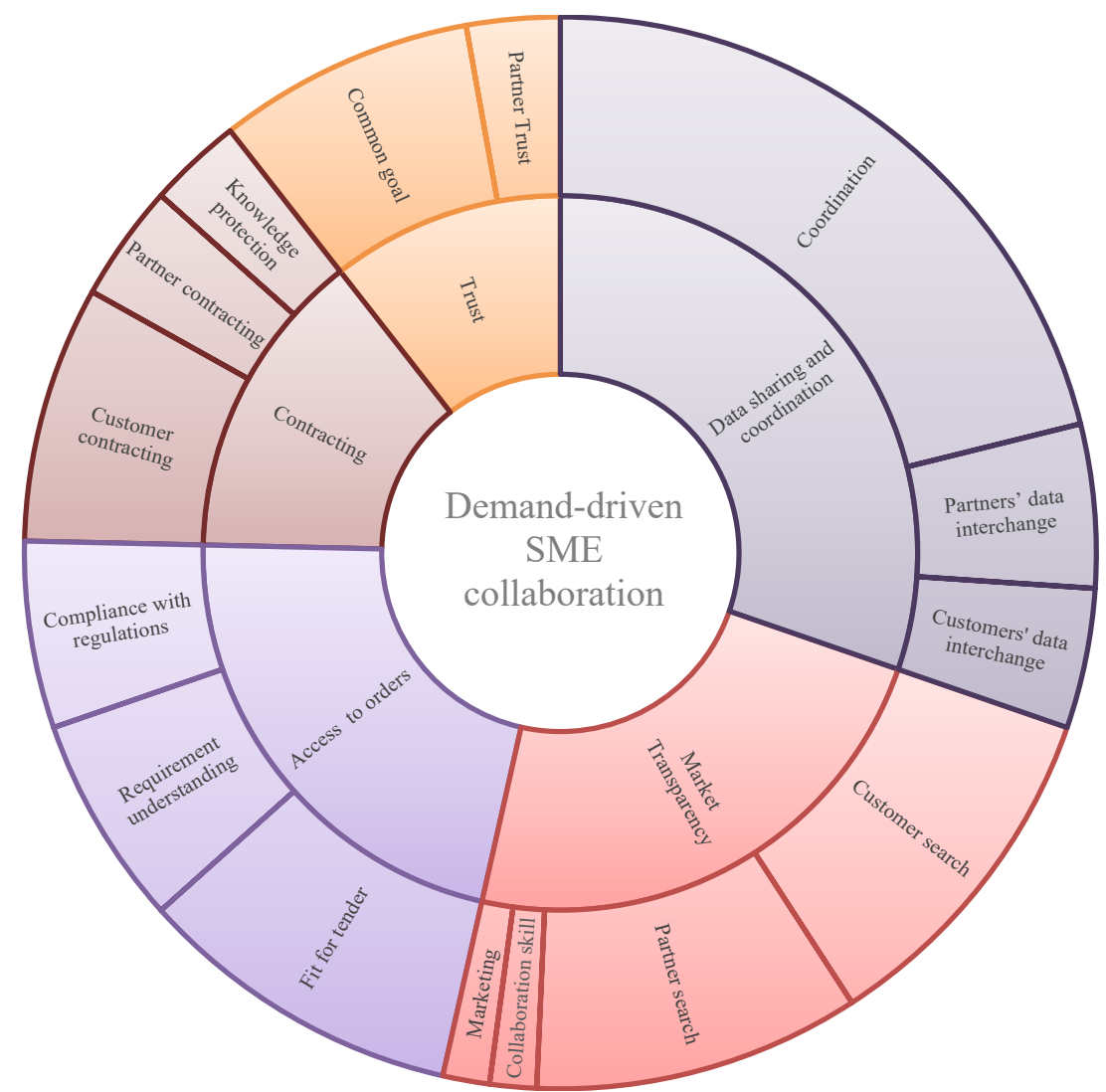

Market Transparency

Access to orders

Trust

Contracting

Data sharing and coordination

Figure 3. Factors driving supply-side SME collaboration via removal of barriers. The inner circle refers to overarching themes, while the outer, to barriers. Sector sizes correspond to the number of quotations.

Looking back at the literature, we note similarities in results to other studies. In supply chain alliances, barriers similar to market access have been labelled as 'search for qualified suppliers', 'collaborative skill gap' (Fawcett et al., 2015) and order access: 'silo mentalities' , 'protecting turf'. Knowledge and power imbalance suggest opportunistic behaviour of companies, demonstrating their territoriality (Fawcett et al., 2008). From the SMEs' perspective, many issues are to be agreed before a new collaboration may start (Luthra \& Mangla, 2018). The efforts needed to initiate relationships (Frank et al., 2019) is often a result of a common goal and partner trust. Although lack of trust between SMEs is widely known (Müller et al., 2018), it is still challenging to increase it mutually and make suppliers feel a sense of moral obligation to their peers (Čater \& Čater, 2010). To this end, supplier development programs are useful, such as networking and socialization mechanisms, favouring inter-firm cooperation (Götz \& Jankowska, 2017). The issues related to the unclear legal status of data ownership was identified as substantial impediment in provision of smart 
services (Klein et al., 2018). Restrictive contracting practices were labelled as 'opposition to change' (Fawcett et al., 2008; 2015). The activation of an 'on demand' collaboration includes the official start of the OEM order fulfilment, which provides a further barrier to participation due to coordination issues. 'Poor systems connectivity' and the 'lack of data sharing among supply chain partners' have been identified in supply chain alliances (Fawcett et al., 2008; Fawcett et al., 2015) and in provision of smart services as 'barriers to information exchange' (Klein et al., 2018). Supply chain literature further points to coordination costs arising due to uncertainty and risk (Cachon, 2003; Choi \& Cheng, 2011).

\section{Interrelationships between the barriers and enablers of their reduction}

In the second stage of this study, we report on five causal loop models displaying interrelationships between the barriers, which were produced with AAS and MAC executives. The key concerns discussed with them were: What factors are limiting the growth of SME collaborations in AAS? How do the barriers reinforce each other? What are the potential measures to reduce the barriers? During the discussions with these experts, it was agreed that the following four enablers should address the barriers:

1) Digital platforms, such as $\mathrm{DIGICOR}^{4}$, to facilitate $\mathrm{SME}$ team formation, thus responding to barriers impeding market transparency and access to orders;

2) AAS supplier development programs to address the issues of competitive thinking and lack of knowledge, thus responding to barriers impeding partner trust;

3) Smart contracts such as IOTA ${ }^{5}$ to better regulate relationships with customers and partners, thus responding to barriers impeding contracting;

4) Funding from supra-national institutions, such as the EU's Factories of the Future, to increase the number of companies in AAS which could work in the virtual environment enabled by Industry 4.0, thus responding to barriers impeding data sharing and coordination.

Next, we present the findings by showing interrelationships between barriers and enablers in terms of the five overarching themes: market transparency, order access, partner trust, contracting, and data sharing and coordination.

\footnotetext{
${ }^{4}$ https://www.digicor-project.eu/the-project/ (accessed 1 April 2021)

5 https://www.iota.org/ (accessed 1 April 2021)
} 
Causal loop diagrams with important feedback loops have been developed using the variables identified earlier in the study. As we need to use measurable variables and specify them in a way that their normal sense of direction is positive (Sterman, 2000, p. 153), we conceptualize them as efforts to overcome the barriers (cf. Figure 3). The underlying goal behind causal loop models is to move from reinforcing towards balancing relationships, thus proposing the enablers to change the status quo in the dynamic system (Akkermans \& Van Wassenhove, 2018).

\section{Market transparency}

Figure 4 shows interrelations between barriers that impede market transparency. Barriers are shown in bold, while their impact on market transparency - in regular font. As we can see, customer search increases $(+)$ the order localization ratio. The latter, in turn, increases the number of accomplished tenders, which occurs with a delay, as indicated by two stripes on the arrow. The more tenders are accomplished, the easier it is for a SME to find partners, therefore partner search diminishes (-) directly; as well as customer search diminishes in the longer time perspective indirectly. The reinforcing nature of the loop implies that the more the company spends on customer \& partner search, the easier it is to localize new orders, but these costs reduce the company's profits. The less companies spend on search, the less orders they localize and execute. Therefore, to facilitate market transparency for SMEs, enablers for lowering these barriers should be proposed.

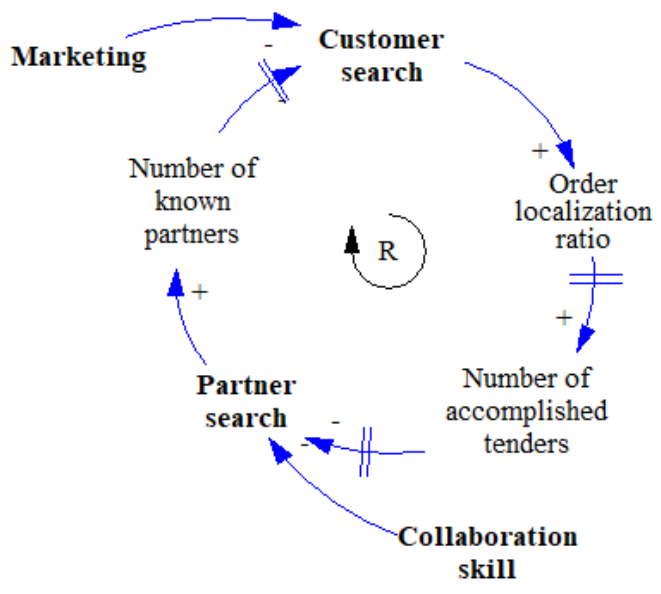

Figure 4. Causal loop diagram of barriers impeding market transparency.

Figure 5 demonstrates that the negative effects of low market transparency could be improved by introducing two enablers (in green): supplier development programs (SDP) and a digital platform 
such as DIGICOR. SDPs include networking and team formation events, which facilitate marketing of SMEs and disseminate best practices of collaboration. DIGICOR is a digital platform developed to increase the number of SME partners and to enable better conditions for order localization. These enablers create balancing loops which reduce the impacts of barriers and reach an equilibrium once a SME finds appropriate order and required partner(s).

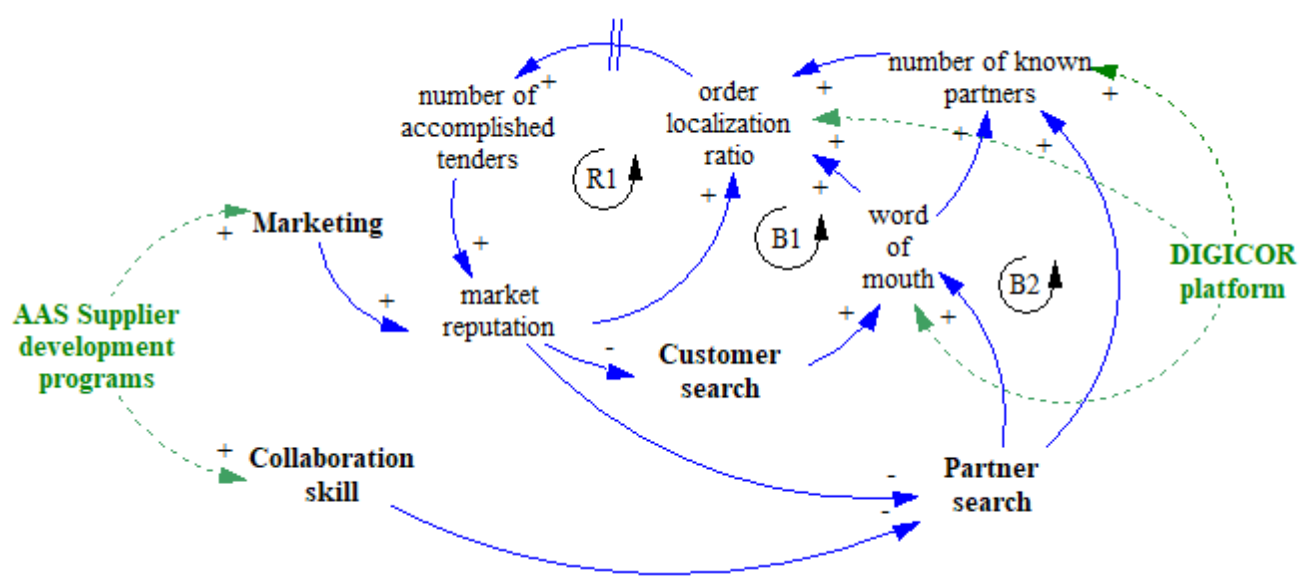

Figure 5. Barriers impeding market transparency. ${ }^{6}$

\section{Order access}

Figure 6 shows interrelations between barriers that impede order access: poor understanding of tendering requirements (R2), lack of direct access to downstream orders (R3) and inability to fit to available calls for tenders. For these barriers, a digital platform enables collaboration governance rules. The reinforcing nature continues until suppliers understand the tendering specification and aerospace regulatory documents, which experts expect in the time perspective.

\footnotetext{
${ }^{6}$ Variables have been selected from the database of companies' responses. Variables in bold are the constructed barriers. The blue arrows show the causal relationships between these barriers and intermediary variables, which increase $(+)$ or decrease (-) in time. Two stripes on the arrow indicate the time delay of causality. Green arrows and green bold variables represent suggested managerial intervention discussed with experts.
} 


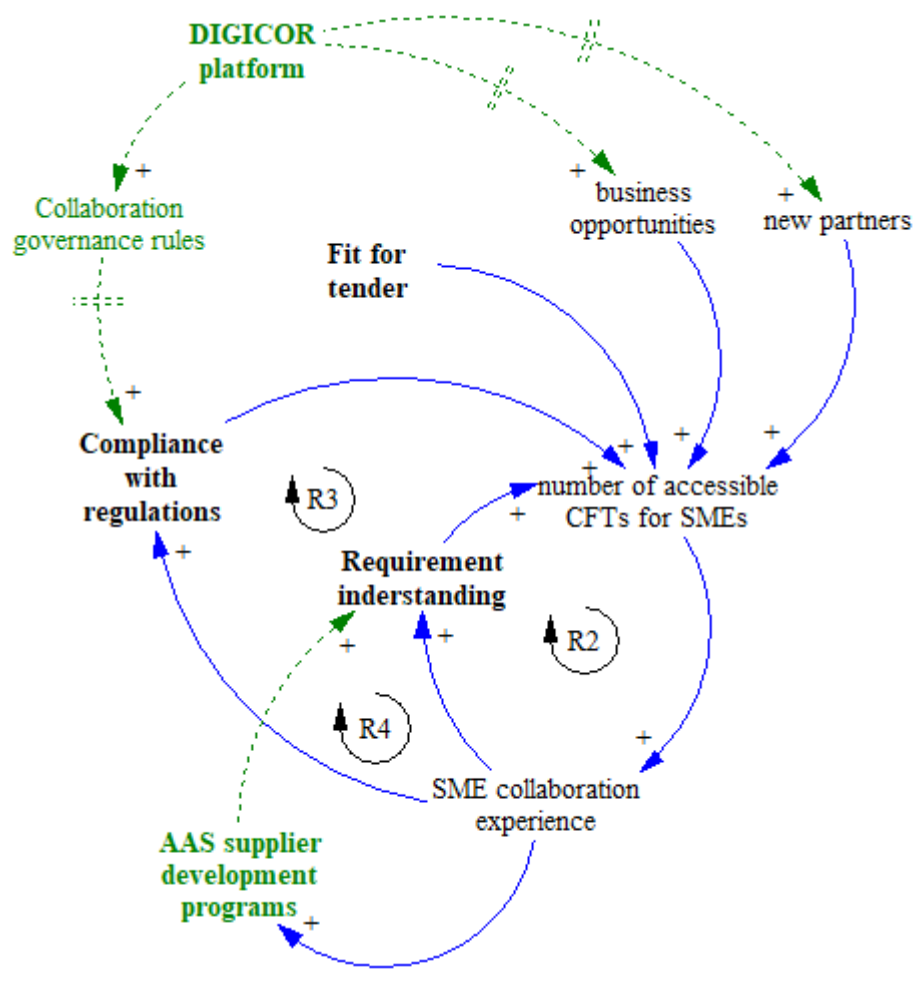

Figure 6. Barriers impeding access to orders.

\section{Partner trust}

Figure 7 shows interrelations between barriers that impede partner trust in AAS, which was identified as the key barrier in an earlier study of multi-tier information sharing in supply chains (Kembro et al., 2017). Partner trust in AAS could be increased by tracing reputation of partners in the standardized legal framework, like smart contracts, which leads to more collaborative work and in turn more common goals (B3). Following the best practice of social dinners in the Virtuelle Fabrik supply cluster (Katzy \& Crowston, 2008), AAS is organizing SDPs and networking events (sea races) for its members to introduce partners, increase their reputation and consequently, confidence in a potential collaboration. 


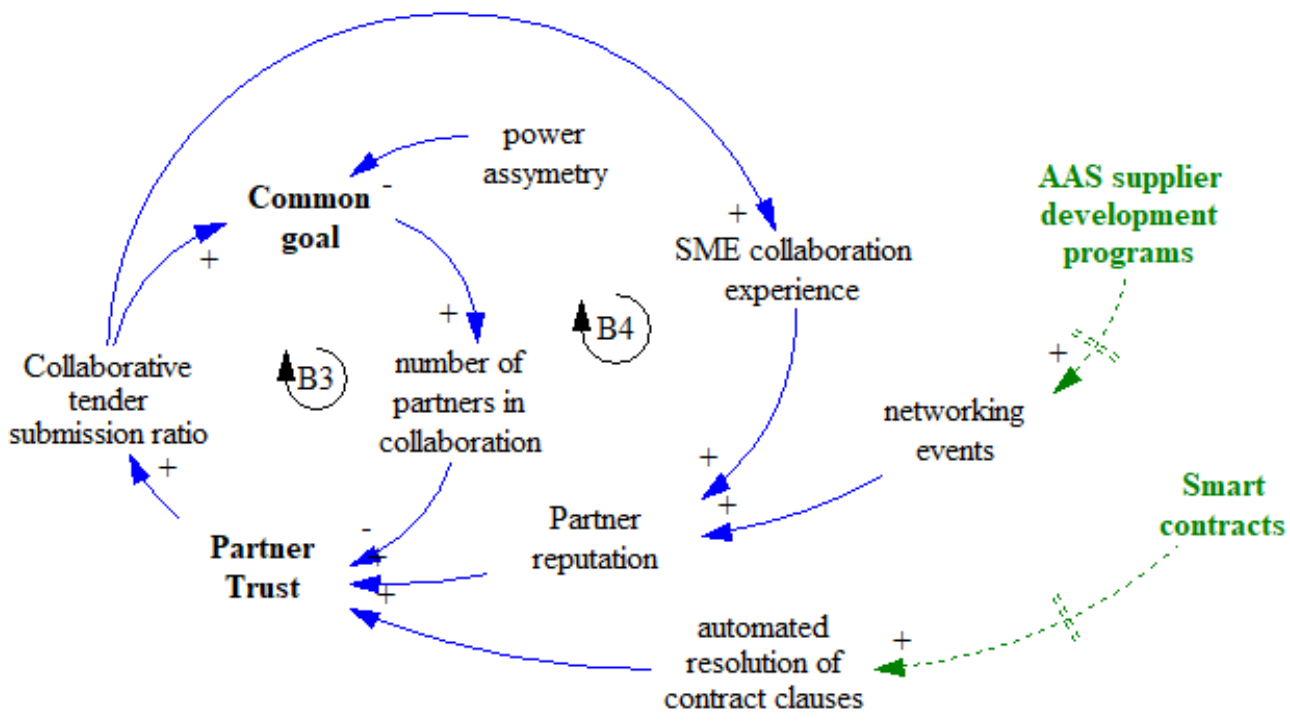

Figure 7. Barriers impeding partner trust.

\section{Partner contracting}

Figure 8 shows interrelations between barriers that impede partner contracting in AAS. Lengthy negotiation times, differences in regulations and unsuitable contract conditions, such as variable ramp-up requests can disturb partner contracting. The enabler targets three variables to reduce risk aversion between SMEs and their efforts of knowledge protection (R6). To this end, smart contracts standardize common legal frameworks to smooth the negative effects. For instance, customer restrictions due to changing contract conditions, such as ramp-up deliveries, or constraints impeding behaviour of new partners could be prescribed in the digital contract, which terminates the execution if the condition is met.

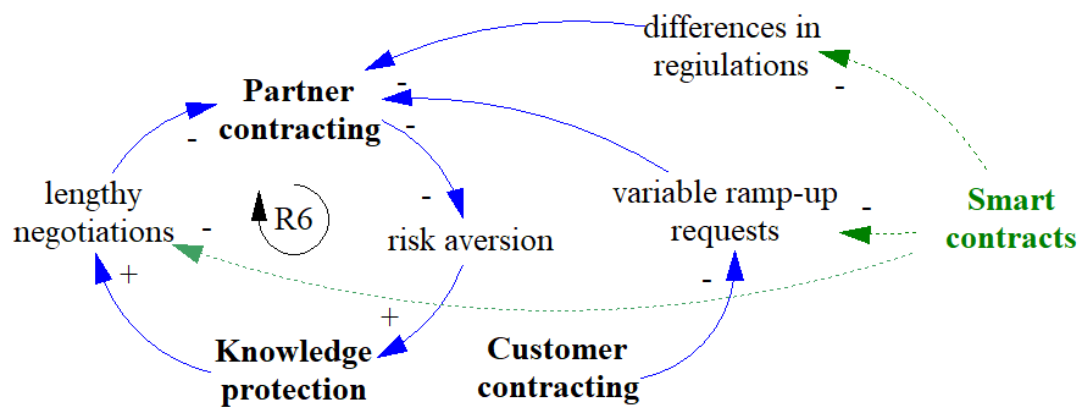

Figure 8. Barriers impeding contracting. 


\section{Data sharing and coordination}

Figure 9 shows interrelations between barriers that impede data sharing and coordination. Lack of delivery specifications, lack of direct interfaces to MAC, and differences in data interchange standards hamper customers' data interchange. Lack of standards in data interchange decreases partners' data interchange ability and consequently coordination efficiency. Funding from supranational institutions, such as the EU, into SME digitalization using Industry 4.0 technologies, such as Internet of Things, enforce data interchange standardization and forecasting abilities, thus starting balancing loop (B5) leading to higher order execution ratio, and the reinforcing loops (R7 and R8) leading to better coordination via improving data exchange between customers and partners. Using these technologies, SMEs could monitor what partners produce, exchange best practices and increase mutual trust, which was earlier referred to as 'learning by monitoring' (Sabel, 1996) in the automotive industry. The COVID-19 restrictions triggered MAC to open an Application Programming Interface (API) for suppliers, which facilitated data exchange of SMEs to MAC and positively impacted on networking and collaboration potential between the AAS members.

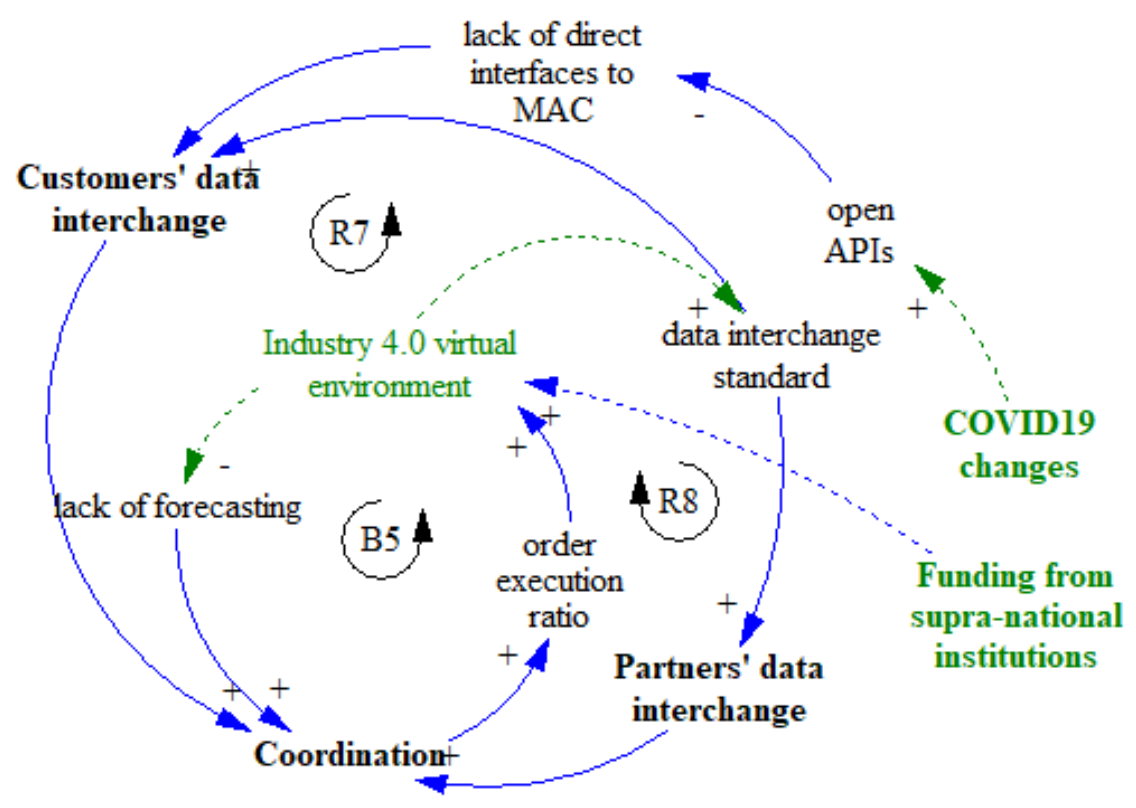

Figure 9. Barriers impeding data sharing and coordination. 


\section{Conclusion}

Our findings offer insights into the barriers impeding demand-driven SME collaborations and potential remedies. Our thematic analysis suggests this is a result of 15 barriers organised into five overarching groups. While some of the barriers have received attention in the operations management literature, they have not been examined in the context of (a) initiating new collaborations, (b) by SMEs, and (c) in the context of digital platforms. This research highlights the role of a SME collaboration as a fertile environment for adopting Industry 4.0 practices and capacity sharing. Although many SMEs cannot adopt Industry 4.0 alone, their demand-driven collaboration can enable partner trust over time and enable solutions for many of the identified barriers. Thus, we provide insights into impediments when a significant effort is needed to identify orders appropriate for collaboration, find partners, initiate, and maintain relationships. The study used a small number of suppliers (17) and may not be generalizable to the population as a whole. We do not argue that the identified barriers represent an exhaustive list, and do not claim causality between the removal of the barriers and collaboration ability. Other industries as well as non-SME contexts should be explored to determine whether these barriers manifest themselves in other settings and whether their removal may lead to an improved demand-driven collaboration.

Future work will focus on simulating system dynamics using the approaches proposed in the present work. We see a pathway to obtaining quantitative insights into the issues raised in this study by including the weighting of barriers, based on frequency of quotation, to stock and flow diagrams as input parameters. These models could therefore provide guidance on the scope of the intervention (e.g., using digital platforms, smart contracts, supplier development programs, and Industry 4.0) needed to overcome a particular barrier or a set of barriers. Building on our findings, studies of cross-industrial nascent platform ecosystems with focus on Industry 4.0 are likely to further extend knowledge in this area and expand the study to industries other than aerospace.

\section{Acknowledgements}

The work presented has received funding from the European Commission under the European Union's Horizon 2020 research and innovation programme (grant agreement no. 723336). We thank Ingo Martens, Arnd Schirrmann and Gash Bhullar for their invaluable input that shaped our work. 


\section{References}

Adner, R., \& Kapoor, R. (2010). Value creation in innovation ecosystems: How the structure of technological interdependence affects firm performance in new technology generations. Strategic Management Journal, 31(3), 306-333.

Akkermans, H. A., \& Van Wassenhove, L. N. (2018). A dynamic model of managerial response to grey swan events in supply networks. International Journal of Production Research, 56(12), 10-21.

Batz, A., Kunath, M., \& Winkler, H. (2018). Discrepancies between cluster services and SMEs' needs constraining the creation of a culture of innovation amidst Industry 4.0. LogForum, 14(3), 387-405.

Bauernhansl, T., Ten Hompel, M., \& Vogel-Heuser, B. (2014). Industrie 4.0 in Produktion, Automatisierung und Logistik: Anwendung-Technologien-Migration. Springer.

Bernhard, J., Peters, M., Janke, J., Starke, J., Jessen, U., Odenthal, B., Miehlke, P., Fischer, R., Ferreira, J. C., Meier-Staude, R., Blomenkamp, D., Göhler, W., Rösner, H., Dupont, W., \& Kottkamp, R. (2007). Abschlussbericht - AerViCo - Aufbau eines Virtuellen Unternehmens in der Luft- und Raumfahrt (BMBF Förderkennzeichen 01HU0160-01HU0169).

Borys, B., \& Jemison, D. B. (1989). Hybrid Arrangements as Strategic Alliances: Theoretical Issues in Organizational Combinations. The Academy of Management Review, 14(2), 234-249.

Braun, V., \& Clarke, V. (2006). Using thematic analysis in psychology. Qualitative Research in Psychology, 3(2), 77-101.

Braziotis, C., Tannock, J. D. T., \& Bourlakis, M. (2017). Strategic and operational considerations for the Extended Enterprise: insights from the aerospace industry. Production Planning \& Control, 28(4), 267-280.

Bryman, A. (2008). Why do researchers integrate/combine/mesh/blend/mix/merge/fuse quantitative and qualitative research. In B. N. (Ed.), Advances in Mixed Methods Research (Vol., pp. 87-100).

Cachon, G. P. (2003). Supply chain coordination with contracts. In S. Graves \& A. de Kok (Eds.), Supply Chain Management: Design, Coordination and Operation (Vol. 11, pp. 227-339).

Camarinha-Matos, L. M. (2009). Collaborative networked organizations: Status and trends in manufacturing. Annual Reviews in Control, 33(2), 199-208.

Camarinha-Matos, L.M., Fornasiero, R., and Afsarmanesh, H., 2017. Collaborative Networks as a Core Enabler of Industry 4.0. In: VLSI-SoC: Design Trends. VLSI-SoC: Design Trends, 317.

Čater, T., \& Čater, B. (2010). Product and relationship quality influence on customer commitment and loyalty in B2B manufacturing relationships. Industrial Marketing Management, 39(8), 1321-1333.

Choi, T.-M., \& Cheng, T. E. (2011). Supply Chain Coordination Under Uncertainty. Springer Science \& Business Media.

Cisneros-Cabrera, S., Pishchulov, G., Sampaio, P., Mehandjiev, N., Liu, Z., \& Kununka, S. (2021). An approach and decision support tool for forming Industry 4.0 supply chain collaborations. Computers in Industry, 125, 103391.

Cisneros-Cabrera, S., Sampaio, P., \& Mehandjiev, N. (2018, 2-7 July 2018). A B2B Team Formation Microservice for Collaborative Manufacturing in Industry 4.0. 2018 IEEE World Congress on Services (SERVICES), 37-38.

Connell, J., Kriz, A., \& Thorpe, M. (2014). Industry clusters: an antidote for knowledge sharing and collaborative innovation? Journal of Knowledge Management, 18(1), 137-151. 
Crabtree, B., \& Miller, W. (1999). Doing qualitative research. Sage Publications. Thousand Oaks, $C A$.

Creswell, J., \& Miller, D. (2010). Determining validity in qualitative inquiry, theory into practice. Theory into Practice, 39(3), 37-41.

Dalmarco, G., Ramalho, F. R., Barros, A. C., \& Soares, A. L. (2019). Providing industry 4.0 technologies: The case of a production technology cluster. The Journal of High Technology Management Research, 30(2), 1-9.

Decker, A. (2017). Industry 4.0 and SMEs in the Northern Jutland Region. In L. J. Marinova S., Nummela N. (Eds), Value Creation in International Business (pp. 309-335). Springer.

Dubey, R., Gunasekaran, A., Childe, S. J., Fosso Wamba, S., Roubaud, D., \& Foropon, C. (2021). Empirical investigation of data analytics capability and organizational flexibility as complements to supply chain resilience. International Journal of Production Research, 59(1), 110-128.

Dubois, A., \& Gadde, L.-E. (2002). Systematic combining: an abductive approach to case research. Journal of Business Research, 55(7), 553-560.

Eisenhardt, K. M., \& Graebner, M. E. (2007). Theory building from cases: Opportunities and challenges. Academy of Management Journal, 50(1), 25-32.

Ethirajan, M., \& Kandasamy, J. (2020). A study on IoT integrated project-driven supply chain in Industry 4.0 environment. Progress in Industrial Ecology, an International Journal, 14(34), 185-199.

Faustino, C. d. A., Gohr, C. F., \& Santos, L. C. (2019). An approach for evaluating collaboration attributes in cluster-based companies. International Journal of Production Research, 57(8), 2356-2371.

Fawcett, S. E., Magnan, G. M., \& McCarter, M. W. (2008). Benefits, barriers, and bridges to effective supply chain management. Supply Chain Management: An International Journal, 13(1), 35-48.

Fawcett, S. E., McCarter, M. W., Fawcett, A. M., Webb, G. S., \& Magnan, G. M. (2015). Why supply chain collaboration fails: the socio-structural view of resistance to relational strategies. Supply Chain Management: An International Journal, 20(6), 648-663.

Fereday, J., \& Muir-Cochrane, E. (2006). Demonstrating rigor using thematic analysis: A hybrid approach of inductive and deductive coding and theme development. International Journal of Qualitative Methods, 5(1), 80-92.

Ferrell, W., Ellis, K., Kaminsky, P., \& Rainwater, C. (2020). Horizontal collaboration: opportunities for improved logistics planning. International Journal of Production Research, 58(14), 4267-4284.

Fisher, F. (1979). Diagnosing Monopoly. Quarterly Review of Economics and Business, 19, 7-33.

Frank, A. G., Dalenogare, L. S., \& Ayala, N. F. (2019). Industry 4.0 technologies: Implementation patterns in manufacturing companies. International Journal of Production Economics, 210 , $15-26$.

Glock, C. H., Grosse, E. H., \& Ries, J. M. (2017). Decision support models for supplier development: Systematic literature review and research agenda. International Journal of Production Economics, 193, 798-812.

Götz, M., \& Jankowska, B. (2017). Clusters and Industry 4.0-do they fit together? European Planning Studies, 25(9), 1633-1653.

Grefen, P., Eshuis, R., Mehandjiev, N., Kouvas, G., \& Weichhart, G. (2009). Internet-based support for process-oriented instant virtual enterprises. IEEE Internet Computing, 13(6), 65-73. 
Grefen, P., Mehandjiev, N., Kouvas, G., Weichhart, G., \& Eshuis, R. (2009). Dynamic business network process management in instant virtual enterprises. Computers in Industry, 60(2), 86-103.

Guo-Qiang, S., \& Ji-Ying, L. (2006). A Theoretical Framework of the Governance Mechanisms in Network Organization. In: IEEE International Conference on Management Science and Engineering, 947-951.

Hernández, V., \& Pedersen, T. (2017). Global value chain configuration: A review and research agenda. BRQ Business Research Quarterly, 20(2), 137-150.

Hoffmann, V. E., Lopes, G. S. C., \& Medeiros, J. J. (2014). Knowledge transfer among the small businesses of a Brazilian cluster. Journal of Business Research, 67(5), 856-864.

Horváth, D., \& Szabó, R. Z. (2019). Driving forces and barriers of Industry 4.0: Do multinational and small and medium-sized companies have equal opportunities? Technological Forecasting and Social Change, 146, 119-132.

Ivanov, D., Das, A., \& Choi, T. (2018). New flexibility drivers in manufacturing, service, and supply chain systems. International Journal of Production Research, 56(10), 3359-3368.

Ivanov, D., Dolgui, A., \& Sokolov, B. (2019). The impact of digital technology and Industry 4.0 on the ripple effect and supply chain risk analytics. International Journal of Production Research, 57(3), 829-846.

Ivanov, D., Sokolov, B., \& Kaeschel, J. (2010). A multi-structural framework for adaptive supply chain planning and operations control with structure dynamics considerations. European Journal of Operational Research, 200(2), 409-420.

Ivanov, D., Tang, C. S., Dolgui, A., Battini, D., \& Das, A. (2020). Researchers' perspectives on Industry 4.0: multi-disciplinary analysis and opportunities for operations management. International Journal of Production Research, 59(7), 1-24.

Janke, J., Starke, J., Bernhard, J., Jessen, U., Peters, M., Odenthal, B., Miehlke, P., Fischer, R., Ferreira, J. C., Meier-Staude, R., Blomenkamp, D., Göhler, W., Rösner, H., Dupont, W., \& Kottkamp, R. (2007). Handlungsleitfaden zum Aufbau und Betrieb eines Virtuellen Unternehmens in Luft- und Raumfahrt (AerViCo - Aerospace Virtual Company).

Kagermann, H., Helbig, J., Hellinger, A., \& Wahlster, W. (2013). Recommendations for implementing the strategic initiative INDUSTRIE 4.0: Securing the future of German manufacturing industry. Industrie 4.0 Working Group.

Kassarjian, H. H. (1977). Content analysis in consumer research. Journal of Consumer Research, $4(1), 8-18$.

Katzy, B. R., \& Crowston, K. (2008). Competency rallying for technical innovation-The case of the Virtuelle Fabrik. Technovation, 28(10), 679-692.

Kazantsev, N., Pishchulov, G., Mehandjiev, N., \& Sampaio, P. (2018). Exploring Barriers in Current Inter-enterprise Collaborations: A Survey and Thematic Analysis. In B. Shishkov (Ed.), Business Modeling and Software Design. BMSD 2018 (Vol. 319, pp. 319-327). Springer International Publishing.

Kembro, J., Näslund, D., \& Olhager, J. (2017). Information sharing across multiple supply chain tiers: A Delphi study on antecedents. International Journal of Production Economics, 193, 77-86.

Kim, J., Dubowitz, H., Hudson-Martin, E., \& Lane, W. (2008). Comparison of 3 data collection methods for gathering sensitive and less sensitive information. Ambul Pediatr, 8(4), 255260.

King, N., \& Horrocks, C. (2010). An introduction to interview data analysis. sage. 
Klein, M. M., Biehl, S. S., \& Friedli, T. (2018). Barriers to smart services for manufacturing companies-an exploratory study in the capital goods industry. Journal of Business \& Industrial Marketing, 33(6), 846-856.

Konsti-Laakso, S., Pihkala, T., \& Kraus, S. (2012). Facilitating SME innovation capability through business networking. Creativity and Innovation Management, 21(1), 93-105.

Lasi, H., Fettke, P., Kemper, H.-G., Feld, T., \& Hoffmann, M. (2014). Industry 4.0. Business \& Information Systems Engineering, 6(4), 239-242.

Liao, T.-J. (2010). Cluster and performance in foreign firms: The role of resources, knowledge, and trust. Industrial Marketing Management, 39(1), 161-169.

Liao, Y., Deschamps, F., Loures, E. d. F. R., \& Ramos, L. F. P. (2017). Past, present and future of Industry 4.0-a systematic literature review and research agenda proposal. International Journal of Production Research, 55(12), 3609-3629.

Luthra, S., \& Mangla, S. K. (2018). Evaluating challenges to Industry 4.0 initiatives for supply chain sustainability in emerging economies. Process Safety and Environmental Protection, 117, 168-179.

MacCarthy, B. L., Blome, C., Olhager, J., Srai, J. S., \& Zhao, X. (2016). Supply chain evolutiontheory, concepts and science. International Journal of Operations \& Production Management, 36(12), 1696-1718.

Machado, C. G., Winroth, M. P., \& Ribeiro da Silva, E. H. D. (2020). Sustainable manufacturing in Industry 4.0: an emerging research agenda. International Journal of Production Research, $58(5), 1462-1484$.

Mahmood, A., Arshad Ali, A., Nazam, M., \& Nazim, M. (2021). Developing an interplay among the psychological barriers for the adoption of industry 4.0 phenomenon. PloS one, 16(8), e0255115.

Martin, D., Romero, I., \& Wegner, D. (2019). Individual, Organizational, and Institutional Determinants of Formal and Informal Inter-Firm Cooperation in SMEs. Journal of Small Business Management, 57(4), 1698-1711.

McKie, L. (2002). Engagement and evaluation in qualitative inquiry. Qualitative Research in Action, Sage, London, 261-285.

Melander, L., \& Lakemond, N. (2015). Governance of supplier collaboration in technologically uncertain NPD projects. Industrial Marketing Management, 49, 116-127.

Michaelides, R., Morton, S. C., Michaelides, Z., Lyons, A. C., \& Liu, W. (2013). Collaboration networks and collaboration tools: a match for SMEs? International Journal of Production Research, 51(7), 2034-2048.

Microsoft (2020). British manufacturers unite to build ventilators for the NHS. https://www.microsoft.com/en-gb/about/ventilator-challenge, accessed 13 Dec 2021.

Miles, M. B., \& Huberman, A. M. (1994). Qualitative data analysis: An expanded sourcebook. sage.

Mittal, S., Khan, M. A., Romero, D., \& Wuest, T. (2018). A critical review of smart manufacturing \& Industry 4.0 maturity models: Implications for small and medium-sized enterprises (SMEs). Journal of Manufacturing Systems, 49, 194-214.

Moeuf, A., Pellerin, R., Lamouri, S., Tamayo-Giraldo, S., \& Barbaray, R. (2018). The industrial management of SMEs in the era of Industry 4.0. International Journal of Production Research, 56(3), 1118-1136.

Moghaddam, M., \& Nof, S. Y. (2018). Collaborative service-component integration in cloud manufacturing. International Journal of Production Research, 56(1-2), 677-691. 
Moradlou, H., Roscoe, S., \& Ghadge, A. (2020). Buyer-supplier collaboration during emerging technology development. Production Planning \& Control, 1-16.

Morgan, D. L. (2007). Paradigms lost and pragmatism regained: Methodological implications of combining qualitative and quantitative methods. Journal of Mixed Methods Research, 1(1), 48-76.

Müller, J. M., Buliga, O., \& Voigt, K.-I. (2018). Fortune favors the prepared: How SMEs approach business model innovations in Industry 4.0. Technological Forecasting and Social Change, $132,2-17$.

Niu, K. H. (2010). Organizational trust and knowledge obtaining in industrial clusters. Journal of Knowledge Management, 14(1), 141-155.

OECD (2017). Enhancing the Contributions of SMEs in a Global and Digitalised Economy. https://www.oecd.org/mcm/documents/C-MIN-2017-8-EN.pdf, accessed 18 Dec 2021.

OECD (2020). The Digital Transformation of SMEs. Report, https://www.oecd.org/industry/smes/PH-SME-Digitalisation-final.pdf, accessed 13 Dec 2021.

Olsen, T. L., \& Tomlin, B. (2020). Industry 4.0: opportunities and challenges for operations management. Manufacturing \& Service Operations Management, 22(1), 113-122.

Panetto, H., Iung, B., Ivanov, D., Weichhart, G., \& Wang, X. (2019). Challenges for the cyberphysical manufacturing enterprises of the future. Annual Reviews in Control, 47, 200-213.

Payne, A., \& Frow, P. (2016). Customer relationship management: Strategy and implementation. In M. Baker \& S. Hart (Eds.). The Marketing Book (pp. 461-488). Routledge.

Pugh, P. (2015). The Magic of a Name: The Rolls-Royce Story, Part 1: The First Forty Years. Icon Books Ltd.

Raj, A., Dwivedi, G., Sharma, A., de Sousa Jabbour, A. B. L., \& Rajak, S. (2020). Barriers to the adoption of industry 4.0 technologies in the manufacturing sector: An inter-country comparative perspective. International Journal of Production Economics, 224, 1-17.

Ramzan, A., Cabrera, S. C., Kazantsev, N., Sampaio, P., \& Mehandjiev, N. (2017). Collaborative Technologies in Automotive and Aerospace Industries towards Industry 4.0. American Conference on Information Systems 2017: International Workshop on Smart Manufacturing: Business Meeting on Big Data Application in Manufacturing.

Reaidy, P. J., Gunasekaran, A., \& Spalanzani, A. (2015). Bottom-up approach based on Internet of Things for order fulfillment in a collaborative warehousing environment. International Journal of Production Economics, 159, 29-40.

Ross, D. F., \& Rogers, J. (1996). Distribution: planning and control. Springer.

Rossen, A., Schlitte, F., Schulze, S., \& Wolf, A. (2015). Volkswirtschaftliche Aspekte des Luftfahrtforschungsprogramms des BMWi, HWWI Policy Paper.

Sabel, C. (1996). Learning-by-monitoring: the dilemmas of regional economic policy in Europe. Networks of enterprises and local development: Competing and co-operating in local productive systems, OECD report, 23-51.

Saunders, M., Lewis, P., \& Thornhill, A. (2007). Research methods. Business Students 4th edition Pearson Education Limited, England.

SCE (2017). Supply Chain Excellence in the German Aerospace Industry. Supply Chain Excellence Initiative, bavAIRia e.V., Germany, https:/www.german-aerospace.de/wpcontent/uploads/2015/08/2017 07 25-Studie-SCE-2017-EN.pdf, accessed 13 Dec 2021.

Schirrmann, A., \& Drat, C. (2018). D6.1: Collaboration rules \& procedures specification. EUfunded project (DIGICOR) deliverable. https://6c97d07e-2d66-4f14-9c19- 
8c5872c4c3ba.filesusr.com/ugd/2512a7_da7dba0ebb164182803d70e03fe6773b.pdf, accessed 13 Dec 2021.

Schor, J. (2014). Debating the Sharing Economy. A Great Transition Initiative Essay. Online: Great Transition Initiative.

Schwab, K. (2017). The fourth industrial revolution. Currency.

Silverman, D., \& Marvasti, A. (2008). Doing qualitative research: A comprehensive guide. Sage.

Smit, J., Kreutzer, S., Moeller, C., \& Carlberg, M. (2016). Industry 4.0 - study for the ITRE Committee. European Parliament, P/A/ITRE/2015-02.

Sokolov, B., \& Ivanov, D. (2015). Integrated scheduling of material flows and information services in industry 4.0 supply networks. IFAC-PapersOnLine, 48(3), 1533-1538.

Sommer, L. (2015). Industrial revolution-industry 4.0: Are German manufacturing SMEs the first victims of this revolution? Journal of Industrial Engineering and Management, 8(5), 15121532.

Spath, D., Ganschar, O., Gerlach, S., Hämmerle, M., Krause, T., \& Schlund, S. (2013). Produktionsarbeit der Zukunft-Industrie 4.0 (Vol. 150). Fraunhofer Verlag Stuttgart.

Stegkemper (2016). Successful Management of Aerospace Supply Chain Networks. Stegkemper GmbH, Germany, https://www.supplyon.com/img/Survey_Digitalization_AerospaceSupply-Chain_2016_EN.pdf, accessed 18 Dec 2021.

Sterman, J. (2000). Business Dynamics: Systems Thinking and Modeling for a Complex World, McGraw Hill, NY.

Tang, C. S., \& Veelenturf, L. P. (2019). The strategic role of logistics in the industry 4.0 era. Transportation Research Part E: Logistics and Transportation Review, 129, 1-11.

Thomas, L. D., Autio, E., \& Gann, D. M. (2014). Architectural leverage: Putting platforms in context. Academy of Management Perspectives, 28(2), 198-219.

Turkina, E., Van Assche, A., \& Kali, R. (2016). Structure and evolution of global cluster networks: evidence from the aerospace industry. Journal of Economic Geography, 16(6), 1211-1234.

Varoutsa, E., \& Scapens, R. (2012). Trust and control building in evolving inter-organisational relationships: Evidence from the aerospace industry. 35th European Accounting Association Annual Congress, 112-140.

Veile, J. M., Schmidt, M.-C., Müller, J. M., \& Voigt, K.-I. (2020). Expected buyer-supplier relationships in the era of Industry 4.0-an analysis across industry sectors. In C. Bode, R. Bogaschewsky, M. Eßig, R. Lasch, W. Stölzle (Eds.) Supply Management Research (pp. 99113). Springer.

Villa, A., \& Bruno, G. (2013). Promoting SME cooperative aggregations: main criteria and contractual models. International Journal of Production Research, 51(23-24), 7439-7447.

Villa, A., \& Taurino, T. (2018). From industrial districts to SME collaboration frames. International Journal of Production Research, 56(1-2), 974-982.

World Bank (2021). Small and Medium Enterprises (SMEs) Finance. Focus area, https://www.worldbank.org/en/topic/smefinance, accessed 18 Dec 2021.

$\mathrm{Xu}, \mathrm{L}$. D., Xu, E. L., \& Li, L. (2018). Industry 4.0: state of the art and future trends. International Journal of Production Research, 56(8), 2941-2962.

Zeng, S. X., Xie, X. M., \& Tam, C. M. (2010). Relationship between cooperation networks and innovation performance of SMEs. Technovation, 30(3), 181-194.

Zimmer, K., Fröhling, M., \& Schultmann, F. (2016). Sustainable supplier management-a review of models supporting sustainable supplier selection, monitoring and development. International Journal of Production Research, 54(5), 1412-1442. 


\section{Appendix}

Table A1. Respondent companies

\begin{tabular}{|c|c|c|c|c|c|}
\hline $\begin{array}{l}\text { Supplier id and } \\
\text { location }\end{array}$ & Sector & Main products / services & $\begin{array}{l}\text { Employees } \\
\text { number }\end{array}$ & $\begin{array}{l}\text { Turnover } \\
\text { in mln. } €\end{array}$ & $\begin{array}{l}\text { Tier } \\
\text { number }\end{array}$ \\
\hline 1 (Europe) & Aerospace & composite aircraft materials & 130 & 12 & 3 \\
\hline 2 (Europe) & Aerospace & $\begin{array}{l}\text { stress analysis, design and } \\
\text { construction }\end{array}$ & 225 & 6.3 & 3 \\
\hline 3 (Europe) & Aerospace & coating of metallic products & 68 & 5.5 & 3 \\
\hline $\begin{array}{l}4 \text { (joint venture of four } \\
\text { European SMEs) }\end{array}$ & Aerospace & maintenance services & $\mathrm{n} / \mathrm{a}^{\dagger}$ & 2.5 & 2 \\
\hline 5 (Europe) & $\begin{array}{l}\text { Aerospace, } \\
\text { automotive } \\
\text { and medical }\end{array}$ & $\begin{array}{l}\text { development and production } \\
\text { of plastics }\end{array}$ & 12 & 1.2 & 2 \\
\hline 6 (Europe) & $\begin{array}{l}\text { Aerospace } \\
\text { and } \\
\text { automotive }\end{array}$ & $\begin{array}{l}\text { plant engineering and } \\
\text { construction }\end{array}$ & 117 & $\mathrm{n} / \mathrm{a}$ & 3 \\
\hline 7 (Europe) & Aerospace & $\begin{array}{l}\text { technology parts from } \\
\text { aluminium and titan }\end{array}$ & 340 & 68 & 2 \\
\hline 8 (Europe) & Aerospace & cabin interiors & 36 & 10 & 2 \\
\hline 9 (Europe) & Aerospace & $\begin{array}{l}\text { manufacturing of painting } \\
\text { systems }\end{array}$ & 5 & 1 & 2 \\
\hline 10 (Europe) & Aerospace & $\begin{array}{l}\text { development of reinforced } \\
\text { elastomers }\end{array}$ & 120 & 7.2 & 3 \\
\hline 11 (Europe) & $\begin{array}{l}\text { Aerospace } \\
\text { and medical }\end{array}$ & $\begin{array}{l}\text { manufacturing of electronic } \\
\text { parts }\end{array}$ & 140 & 30 & 2 \\
\hline 12 (Europe) & Aerospace & $\begin{array}{l}\text { equipment for ground } \\
\text { support and testing }\end{array}$ & 150 & 16 & 2 \\
\hline $\begin{array}{l}13 \text { (Autonomous } \\
\text { European branch of a } \\
\text { global company) }\end{array}$ & Aerospace & $\begin{array}{l}\text { logistic services for } \\
\text { transports in air, sea, land } \\
\text { (road, railroad) }\end{array}$ & 16,000 & $\mathrm{n} / \mathrm{a}^{\dagger}$ & 2 \\
\hline $\begin{array}{l}14 \text { (Autonomous } \\
\text { European branch of a } \\
\text { global company) }\end{array}$ & $\begin{array}{l}\text { Aerospace } \\
\text { and } \\
\text { automotive } \\
\text { services }\end{array}$ & $\begin{array}{l}\text { consulting, systems } \\
\text { engineering, physical } \\
\text { engineering, testing }\end{array}$ & 600 & 58 & 2 \\
\hline 15 (Europe) & $\begin{array}{l}\text { Research and } \\
\text { innovation }\end{array}$ & $\begin{array}{l}\text { consulting and strategy } \\
\text { development }\end{array}$ & 3 & 0.3 & 2 \\
\hline 16 (Europe) & Aerospace & $\begin{array}{l}\text { product testing, } \\
\text { environmental simulation }\end{array}$ & 15 & 1.5 & 3 \\
\hline 17 (European) & Aerospace & $\begin{array}{l}\text { metalworking and surface } \\
\text { finishing }\end{array}$ & 63 & 3.7 & 2 \\
\hline
\end{tabular}

$\dagger$ The data supplied in this entry has been designated as unusable. 
Table A2. List of questions for the identification of benefits and barriers

\begin{tabular}{|c|c|c|c|c|}
\hline 1 & Sector of your Company: & \multicolumn{3}{|l|}{ Free Text } \\
\hline 2 & Main Products /Main Services: & \multicolumn{3}{|l|}{ Free Text } \\
\hline 3 & Size of your Company & Micro & Small & Medium \\
\hline 4 & Member of Clusters & \multicolumn{3}{|l|}{ Free Text } \\
\hline 5 & Main Customers & $\begin{array}{l}\text { Supply } \\
\text { Chain - } \\
\text { Level }\end{array}$ & $\begin{array}{l}\text { SME? } \\
(\mathrm{Y} / \mathrm{N})\end{array}$ & $\begin{array}{l}\text { After } \\
\text { Sales? } \\
(\mathrm{Y} / \mathrm{N})\end{array}$ \\
\hline 6 & Main Suppliers and Main Delivery Products/Services & $\begin{array}{l}\text { Supply } \\
\text { Chain - } \\
\text { Level }\end{array}$ & $\begin{array}{l}\text { SME? } \\
(\mathrm{Y} / \mathrm{N})\end{array}$ & $\begin{array}{l}\text { After } \\
\text { Sales? } \\
(\mathrm{Y} / \mathrm{N})\end{array}$ \\
\hline \multicolumn{5}{|c|}{ SCM-related questions: } \\
\hline 7 & What are your top three activities to find customers? & \multicolumn{3}{|l|}{ Free Text } \\
\hline 8 & What are your top three priorities for your business at present? & \multicolumn{3}{|l|}{ Free Text } \\
\hline 9 & $\begin{array}{l}\text { What are the main barriers/problems for integration of your } \\
\text { company in supply chains of your customers (e.g. OEM, } 1^{\text {st }} \text { tier } \\
\text { suppliers)? }\end{array}$ & \multicolumn{3}{|l|}{ Free Text } \\
\hline 10 & $\begin{array}{l}\text { What are the main impacts of the barriers/problems on your } \\
\text { business? }\end{array}$ & \multicolumn{3}{|l|}{ Free Text } \\
\hline 11 & $\begin{array}{l}\text { Do you partner with other organisations in addressing business } \\
\text { opportunity and delivering your product or service? }\end{array}$ & \multicolumn{3}{|l|}{ Free Text } \\
\hline 12 & $\begin{array}{l}\text { What are your main activities to find partners and organisations } \\
\text { for collaboration? }\end{array}$ & \multicolumn{3}{|l|}{ Free Text } \\
\hline 13 & $\begin{array}{l}\text { What are the main problems does your company have with } \\
\text { collaboration of SME/organisations in networks? }\end{array}$ & \multicolumn{3}{|l|}{ Free Text } \\
\hline 14 & $\begin{array}{l}\text { Which information deficits regarding supply chain management } \\
\text { (SCM) does your company have? }\end{array}$ & \multicolumn{3}{|l|}{ Free Text } \\
\hline 15 & $\begin{array}{l}\text { Which solutions of the mentioned problems in SCM you can } \\
\text { recommend? }\end{array}$ & \multicolumn{3}{|l|}{ Free Text } \\
\hline 16 & $\begin{array}{l}\text { Have you participated in a SME network in the past? } \\
\text { If YES, which ones: }\end{array}$ & \multicolumn{3}{|l|}{ Free Text } \\
\hline 17 & Why has your company decided to participate in a network? & \multicolumn{3}{|l|}{ Free Text } \\
\hline 18 & How your company will decide whether to join a network? & \multicolumn{3}{|l|}{ Free Text } \\
\hline 19 & $\begin{array}{l}\text { What are the top three benefits from participating in a SME } \\
\text { network supported by digital platforms? }\end{array}$ & \multicolumn{3}{|l|}{ Free Text } \\
\hline 20 & What are your comments or recommendations? & \multicolumn{3}{|l|}{ Free Text } \\
\hline
\end{tabular}


Table A3. Overarching themes, barriers, number of corresponding answers, and quotations

\begin{tabular}{|c|c|c|c|}
\hline $\begin{array}{l}\text { Overarching } \\
\text { Themes }\end{array}$ & Barriers & $\mathbf{N}$ & Representative proof quotations \\
\hline \multirow{4}{*}{$\begin{array}{l}\text { Barriers } \\
\text { impeding } \\
\text { market } \\
\text { transparency }\end{array}$} & Customer search costs & 15 & $\begin{array}{l}\text { [need to] "attend physical industry trade fairs and presentation } \\
\text { events to find new customers" }\end{array}$ \\
\hline & Partner search costs & 14 & "networking time is missing" \\
\hline & Marketing costs & 2 & $\begin{array}{l}\text { [spending required to sustain] "reputation and marketing effort" } \\
\text { [otherwise, it is] "very difficult to find new customers" }\end{array}$ \\
\hline & $\begin{array}{l}\text { Lack of knowledge } \\
\text { about starting new } \\
\text { relationship in } \\
\text { Industry } 4.0\end{array}$ & 1 & $\begin{array}{l}\text { "a lack of knowledge [about] how to collaborate in networks and } \\
\text { Industry } 4.0 "\end{array}$ \\
\hline \multirow{3}{*}{$\begin{array}{l}\text { Barriers } \\
\text { impeding } \\
\text { access to } \\
\text { customer } \\
\text { orders }\end{array}$} & $\begin{array}{l}\text { SME suppliers unable } \\
\text { to meet the tender } \\
\text { requirements }\end{array}$ & 14 & $\begin{array}{l}\text { "the size of our company is too small for very high-volume } \\
\text { contracts with the OEM" }\end{array}$ \\
\hline & $\begin{array}{l}\text { Lack of direct access } \\
\text { to downstream orders }\end{array}$ & 8 & $\begin{array}{l}\text { "1st-tier supplier bought some suppliers as subsidiaries and no } \\
\text { other suppliers have the chance to deliver"; "big customers want } \\
\text { to have all services from one source" }\end{array}$ \\
\hline & $\begin{array}{l}\text { Lack of understanding } \\
\text { of requirements }\end{array}$ & 9 & $\begin{array}{l}\text { [requirements]: "vague", "unclear"; [unknown]: "contact person } \\
\text { at the customer" }\end{array}$ \\
\hline \multirow[b]{2}{*}{$\begin{array}{l}\text { Barriers } \\
\text { impeding } \\
\text { partner trust }\end{array}$} & Partner opportunism & 11 & $\begin{array}{l}\text { "competition thinking"; "to find common goals"; 'some SMEs are } \\
\text { looking for the "cheap win": i.e. getting as much out of } \\
\text { collaboration as possible without providing anything "in } \\
\text { exchange", }\end{array}$ \\
\hline & Partner distrust & 4 & $\begin{array}{l}\text { [there is] "(no) willingness to further develop external ideas [that } \\
\text { are] not invented by them [and] top management [of other } \\
\text { companies] disapprove of the idea of collaborating with other } \\
\text { organisations altogether"; "evaluation of own suppliers can't be } \\
\text { done because reluctance of those to deliver the required } \\
\text { information"; [suppliers mentioned intentions] "to spy for } \\
\text { solutions of competitors" }\end{array}$ \\
\hline \multirow{3}{*}{$\begin{array}{l}\text { Barriers } \\
\text { impeding } \\
\text { contracting }\end{array}$} & $\begin{array}{l}\text { Restrictive } \\
\text { contracting practices }\end{array}$ & 11 & $\begin{array}{l}\text { [customers'] "unwillingness to change suppliers"; } \\
\text { [Smaller suppliers] "can't take part in tenders, if they don't have a } \\
\text { contract with OEM"; "long-term contract terms with changing } \\
\text { business content" }\end{array}$ \\
\hline & $\begin{array}{l}\text { Partner contracting } \\
\text { costs }\end{array}$ & 5 & $\begin{array}{l}\text { [the existence of] "international different systems for law, taxes } \\
\text { and patents"; [it takes] "long time to find right regulations"; [and } \\
\text { to decide about the] "role[s] in the cooperation (Who is the } \\
\text { contractor?)"; "SME partners want to have own contracts with the } \\
\text { customer". }\end{array}$ \\
\hline & $\begin{array}{l}\text { Knowledge protection } \\
\text { costs }\end{array}$ & 4 & $\begin{array}{l}\text { "IP- and knowledge-management in projects [that] disable } \\
\text { cooperation"; "difficult contracts and different international } \\
\text { systems for law, taxes and patents"; "problems with intellectual } \\
\text { property"; "time-consuming non-disclosure agreements" }\end{array}$ \\
\hline \multirow{3}{*}{$\begin{array}{l}\text { Barriers } \\
\text { impeding data } \\
\text { sharing and } \\
\text { coordination }\end{array}$} & $\begin{array}{l}\text { Costs of data } \\
\text { interchange with } \\
\text { customers }\end{array}$ & 6 & $\begin{array}{l}\text { "direct IT-interface to the [OEM] systems" [is limited]; "time- } \\
\text { consuming calibration because of missing knowledge for operating } \\
\text { devices of customers". }\end{array}$ \\
\hline & $\begin{array}{l}\text { Lack of ability to } \\
\text { utilize partners' data }\end{array}$ & 7 & $\begin{array}{l}\text { "unfit technological delivery specifications"; "missing standards } \\
\text { and interfaces in communication" "proprietary IT-systems without } \\
\text { adequate standards for data transfer",; "optimization in } \\
\text { information flows and communication for structured data } \\
\text { exchange" }\end{array}$ \\
\hline & $\begin{array}{l}\text { Cost of lack of } \\
\text { coordination }\end{array}$ & 30 & $\begin{array}{l}\text { "Chinese whispers effects in communication"; "long production } \\
\text { cycles of suppliers [shift] estimated delivery time and [therefore] } \\
\text { delivery requirements of customers [are getting] not compatible" }\end{array}$ \\
\hline
\end{tabular}

